\title{
Cationic Liposome-Encapsulated Paclitaxel
}

National Cancer Institute

\section{Source}

National Cancer Institute. Cationic Liposome-Encapsulated Paclitaxel. NCI Thesaurus.

Code C69130.

A cationic liposome preparation of paclitaxel with antineoplastic activity. Paclitaxel, the active ing redient in cationic liposome-encapsulated paclitaxel, binds to tubulin and inhibits the disassembly of microtubules, resulting in the inhibition of mitosis and cellular proliferation, and apoptosis. Cationic liposome encapsulation of paclitaxel allows the delivery of high doses of paclitaxel to target tissues while minimizing systemic toxicity. Tumor endothelial cells may preferentially bind and internalize cationic liposomes. 